\title{
Article \\ Development and Characterization of Arrowroot Starch Films Incorporated with Grape Pomace Extract
}

\author{
Gislaine Ferreira Nogueira ${ }^{1, *(\mathbb{C}}$, Isabela Helena Bratfischer Tagliari Soares ${ }^{2}\left(\mathbb{D}\right.$, Cyntia Trevisan Soares ${ }^{2}(\mathbb{D}$, \\ Farayde Matta Fakhouri ${ }^{3,4}\left(\mathbb{D}\right.$ and Rafael Augustus de Oliveira ${ }^{2}$ (1) \\ 1 Academic Unit of Passos, Minas Gerais State University, Passos 37900-106, MG, Brazil \\ 2 School of Agricultural Engineering, University of Campinas, Campinas 13083-875, SP, Brazil; \\ isabelahbts@gmail.com (I.H.B.T.S.); cyntiatrevisan@gmail.com (C.T.S.); \\ augustus@feagri.unicamp.br (R.A.d.O.) \\ 3 Poly2 Group, Department of Materials Science and Engineering, Universitat Politècnica de Catalunya, \\ Carrer Colom 11, E-08222 Terrassa, Spain; farayde.matta@upc.edu \\ 4 Faculty of Engineering, Federal University of Grande Dourados, Dourados 79804-970, MS, Brazil \\ * Correspondence: gislainefnogueira@gmail.com; Tel.: +55-19-997-629-917
}

check for updates

Citation: Nogueira, G.F.; Soares, I.H.B.T.; Soares, C.T.; Fakhouri, F.M.; de Oliveira, R.A. Development and Characterization of Arrowroot Starch Films Incorporated with Grape

Pomace Extract. Polysaccharides 2022, 3, 250-263. https://doi.org/10.3390/ polysaccharides 3010014

Academic Editors: Alessandra Braga Ribeiro and Ricardo J. B. Pinto

Received: 21 January 2022

Accepted: 18 February 2022

Published: 23 February 2022

Publisher's Note: MDPI stays neutral with regard to jurisdictional claims in published maps and institutional affiliations.

Copyright: (C) 2022 by the authors. Licensee MDPI, Basel, Switzerland. This article is an open access article distributed under the terms and conditions of the Creative Commons Attribution (CC BY) license (https:// creativecommons.org/licenses/by/ $4.0 /)$

\begin{abstract}
Grape processing residues are a good source of bioactive and nutritional compounds. The incorporation of grape pomace extract (GPE) in starch films can be a strategy for the elaboration of new food packaging products for applications such as edible films or fruit strips. In this context, the objective of this research was to analyze the effect of incorporation and variation of concentration of GPE $(0,20,30$, and $40 \%$ mass / mass starch solids) on the physical chemical properties of arrowroot starch edible films created by casting. The GPE was characterized for moisture content, $\mathrm{pH}$, total titratable acidity, total soluble solids, and anthocyanin content. Starch films with and without GPE were evaluated by analyzing their visual appearance, water activity, water content, thickness, water solubility, and water vapor permeability. The GPE had high water content, acidity, and anthocyanins content. The films with GPE showed a noticeable reddish color, similar to observed for the GPE. Increasing the concentration of GPE in the film resulted in significantly increased $(p<0.05)$ thickness (from 0.060 to $0.106 \mathrm{~mm}$ ), water content (from 8.17 to $12.48 \%$ ), solubility in water (from 13.33 to $33.32 \%$ ), and water vapor permeability (from 3.72 to $6.65 \mathrm{~g} . \mathrm{mm} / \mathrm{m}^{2}$ day $\mathrm{kPa}$ ). GPE increased the hydrophilic portion of the film, in addition to acting as a plasticizer, decreasing the molecular interactions of the polymer chain, and favoring its solubilization, which is desirable for applications such as edible films. The elaboration of arrowroot starch films with the incorporation of grape pomace is a good alternative for the reduction of by-products of grape processing.
\end{abstract}

Keywords: environment; agro-industrial residues; grape pomace; BRS Violeta; Maranta arundinacea Linn.; biopolymers; edible packaging; solubility in water; permeability to water vapor

\section{Introduction}

The grape (Vitis sp.) is a fruit with great worldwide and national production [1]. In Brazil, 1,702,660 tons of grape were produced in 2021. In 2020, Brazil produced $1,416,398$ tons of grapes and 360 million liters of wine were produced from this harvest season [2]. American grapes and hybrids are the most used in wine production [3]. Cultivar BRS Violeta is a hybrid generated by crossing between BRS Rúbea and IAC 1398-21 by the Brazilian Agricultural Research Corporation (EMBRAPA, Brasilia, Brazil). This cultivar is recommended for the production of juice and red table wine. The fruit of BRS Violeta cultivar is characterized by its spherical shape with a bluish-black skin and colored pulp, in addition to a raspberry flavor [4].

Grapes are consumed fresh or processed in the form of juices, jellies, and wines [1], which result in a large amount of residues that impact the environment. This is because only about $3 \%$ of waste from the wine industry undergoes a recovery process. Pomace is the 
main solid residue from winemaking, accounting for about $20 \%$ to $30 \%$ of the total weight of processed grapes [5,6]. Grape pomace consists mainly of skins, seeds, and sometimes stalks. It is abundant in phenolic compounds [7-9], lipids, waxes [6], proteins [6], and polysaccharides [10], in addition to other value-added products, such as unfermented sugars, pigments, alcohol, tannins [11], dietary fiber with cellulose, hemicellulose, pectin, and lignin [1]. Due to its abundance and variety of compounds of interest, grape pomace has a high potential for application in functional food products and nutraceuticals. The nutritional profile of tagliatelle pasta [12], cakes [13], and coconut water [14] were improved with the incorporation of grape pomace or its extract.

Some research works have studied methods of extraction and quantitative and qualitative analysis of phenolic compounds present in grape pomace [7-9]. At the same time, other works have focused on the incorporation of grape pomace extract in bioactive, edible, and biodegradable films $[6,15,16]$. Chitosan-based films proved to be promising vehicles for functional compounds with antioxidant properties due to incorporation of grape pomace extracts [6]. For Kurek et al. [15], the incorporation of red grape skin pomace extract, further to generating antioxidant activity on the chitosan films, also increased their solubility in water and the permeability to water vapor in comparison to the control film, indicating changes in their polarities.

Currently, the use of biopolymers made from renewable by-products from agriculture and waste from the food industry has emerged as an essential alternative to reach the ecological needs of a sustainable environment and consumer demands for products closer to being natural [15-22]. Starch is the most studied low-cost biopolymer due to its biocompatibility, biodegradability, and absence of toxicity [23] and because it is widely purchased from several sources such as arrowroot [24]. Arrowroot starch has attracted the interest of Brazilian food industries due to reports of its high digestibility [25], which allows its use in feeding children, the elderly, or patients with bowel disorders [26]. In addition, its high amylose content allows the formation of continuous matrices which result in films with good functional properties [24].

The combination of arrowroot starch and grape pomace extract can generate improved physicochemical properties to the resulting edible film, such as innovative color and flavor, nutritional compounds and a desirable high solubility in order to facilitate its disintegration when consumed alone or in combination with packaged food.

Gutierrez et al. [16] produced edible films from Guinea arrowroot starch (Calathea allouia) with grape waste flour and grape waste ethanolic extract (Vitis vinifera) by blending followed by thermos molding. Analyses of in vitro digestibility, as well as structural properties (thermogravimetric, X-ray diffraction, and differential scanning calorimetry analysis) of the films, revealed that the films made with natural fillers had a reduced in vitro digestibility rate, were less hydrophilic, and more thermal resistant, in addition to tending to have a ductile mechanical behavior [16]. Although $\mathrm{pH}$-sensitive films have already been made with arrowroot starch and grape residue flour, data in the scientific literature about the effect of this combination on the basic characteristics of the films are still scarce.

Further studies are needed to evaluate the compatibility and concentration of the grape pomace extract in relation to the film-forming polymer, since the basic properties, such as water content, thickness, water solubility, and water vapor permeability of the resulting film depend on this adjustment and the proportion between them, and can indicate its application. The physicochemical properties of biopolymer films are not only governed by the type of material used for forming the basic matrix, but also by the type and concentration of incorporated extract [27]. Therefore, in this study, edible films were developed from arrowroot starch (Maranta arundinacea Linn.) with grape pomace aqueous extract (BRS Vitória) at different concentrations (0, 20,30, and 40\% mass of GPE/mass of starch solids) by casting. The effect of GPE incorporation and variation of its concentration in the starch film was evaluated by analyzing its visual appearance, water activity, water content, thickness, water solubility, and water vapor permeability. The results obtained in 
this study could be used in the future to design films as transport vehicles for nutritional compounds, as well as bioactive compounds.

\section{Materials and Methods}

\subsection{Materials}

Frozen BRS Violeta grapes were obtained by donation and used in this research work for the production of grape pomace extract (GPE). In elaboration of edible films containing GPE, native arrowroot (Maranta arundinacea Linn.) starch was used as a film-forming solution and glycerol P.A. (Reagen, Quimibrás Indústrias Químicas S.A., Rio de Janeiro, Brazil) as a plasticizing agent. Arrowroot starch was previously characterized by Nogueira, Fakhouri, and Oliveira [24], presenting $15.24 \pm 0.19 \%$ of water, $0.40 \pm 0.03 \%$ of protein, $0.12 \pm 0.01 \%$ of fat, $0.33 \pm 0.01 \%$ ash, and $83.91 \pm 0.10 \%$ of carbohydrates (previously determined according to AOAC [28]) and amylose content of $35.20 \pm 1.63 \%$ (determined according to method described by Martínez [29]). All reagents used in this research were of analytical grade.

\subsection{Preparation of Grape Pomace Extract (GPE)}

For the production of GPE, the grape berries were thawed at a temperature of $4{ }^{\circ} \mathrm{C}$ for $12 \mathrm{~h}$. Afterward, the grapes were separated from the stalks and selected by removing the fruits that showed deterioration characteristics, washed in running water to remove dirt, and sanitized by submersion in water with 10\% sodium hypochlorite for $3 \mathrm{~min}$. Then, the berries were pressed in a mechanical press with subsequent separation of pomace from must by filtration. For preparation of the extract, pomace was homogenized and liquefied with water in proportion of 1:1 (pomace mass/water mass) until obtain a paste. This paste was then strained to separate the liquid extract. The extract obtained was stored at $-18{ }^{\circ} \mathrm{C}$ in polypropylene vials protected with aluminum foil against photodegradation.

\section{Characterization of the Grape Pomace Extract (GPE)}

The grape pomace extract was characterized for moisture content, total soluble solids, $\mathrm{pH}$, total titratable acidity, and anthocyanin content, in triplicate.

The water content was determined by drying the liquid extract in vacuum oven at $60{ }^{\circ} \mathrm{C}$ and pressure of $84.660 \mathrm{~Pa}$, until constant weight. Total soluble solids were determined by direct reading in a digital bench refractometer (Reichert, Model 1310499, Depew, NY, USA), which expresses their values in ${ }^{\circ}$ Brix, following AOAC's official methodology [30].

Direct reading of the homogenized grape poma extract using potentiometer (Digimed, $\mathrm{pH}$ meter DM-22, São Paulo, Brazil) performed the $\mathrm{pH}$ measurement. The total titratable acidity of grape pomace extract was determined by titrating $10 \mathrm{~g}$ of the homogenized sample with $90 \mathrm{~mL}$ of distilled water utilizing sodium hydroxide solution $(0.1 \mathrm{~N} \mathrm{NaOH})$ as titrator and $\mathrm{pH} 8.1$ as the turning point measured by a potentiometer (Digimed $\mathrm{pH}$ meter DM-20). Results were expressed as percentage of tartaric acid [30].

To quantify the anthocyanin content, the grape pomace extract samples were homogenized with $3 \mathrm{~mL}$ of cold acetone/Tris- $\mathrm{HCl}$ solution (80:20, volume/volume, $\mathrm{pH} 7.80 .2 \mathrm{M}$ ) for $1 \mathrm{~min}$, and left to rest for $5 \mathrm{~min}$ protected from light. Sample supernatants were read in a spectrophotometer (model Q798U2M, Quimis ${ }^{\circledR}$, São Paulo, Brazil) in the visible region at $537 \mathrm{~nm}$ (anthocyanins) after centrifugation for $15 \mathrm{~min}$ at $3500 \mathrm{rpm}$ following methodology described by Sims and Gamon [31]. Acetone/Tris-HCl solution was used as blank sample. Absorbance values were converted to $\mathrm{mg} \mathrm{g}^{-1}$ of fresh sample.

\subsection{Edible Film Production}

Edible films were made using the casting technique. The film-forming solution made with $4 \%(\mathrm{~m} / \mathrm{m})$ of arrowroot starch was gelatinized at $85 \pm 2{ }^{\circ} \mathrm{C}$ in a thermostatic bath (Tecnal, Piracicaba, Brazil) for around 10 min with constant manual agitation, as optimized by Nogueira, Fakhouri, and Oliveira [24]. The film-forming solution was then incorporated with grape pomace extract in concentrations of $0,20,30$, and $40 \%$ (mass of extract 
solids/starch mass) plus 17\% of glycerol (glycerol mass/mass of starch plus mass of grape extract solids) and homogenized [32]. Then, $25 \mathrm{~mL}$ of the solutions were placed on support plates $\left(12 \mathrm{~cm}\right.$ in diameter) and dried at a temperature of $25^{\circ} \mathrm{C}$. For each formulation, at least 30 films were made from 6 different film-forming solutions. After $24 \mathrm{~h}$, the dried films were removed from the support plates and stored at $25^{\circ} \mathrm{C}$ and $55 \pm 3 \%$ of relative humidity for $48 \mathrm{~h}$ before characterization.

\subsubsection{Visual Aspect}

Visual and tactile analyses were carried out for the selection of homogeneous films, without cracks and ones that were flexible to handling [33].

\subsubsection{Film Thickness, Water Activity, and Moisture Content}

Thickness was determined at ten distinct positions of each film sample utilizing a digital micrometer (Mitutoyo, model MDC 25 M, MFG, Kawasaki, Japan) with accuracy of $\pm 0.001 \mathrm{~mm}$ [33]. An AquaLab Lite water activity meter (Decagon Devices Inc., Pullman, WA, USA) was used to determine the water activity of the film samples. The results were obtained by direct measurement on the device, at $25^{\circ} \mathrm{C}$, in triplicate, expressed in decimal values [33]. The films were dried in oven without air circulation at $105{ }^{\circ} \mathrm{C}$ for $24 \mathrm{~h}$, in triplicate, to determine the moisture content [28].

\subsubsection{Solubility in Water}

Water solubility analysis was performed using the method proposed by Gontard et al. [34]. Film samples were cut in circumferences of $2 \mathrm{~cm}$ in diameter, in triplicate. The initial percentage of dry matter of each sample was gravimetrically quantified by its dehydration in oven at $105{ }^{\circ} \mathrm{C}$ for $24 \mathrm{~h}$. Dried films were individually added into $50 \mathrm{~mL}$ of distilled water with mechanical stirring $(75 \mathrm{rpm})$ for $24 \mathrm{~h}$ at $25 \pm 2{ }^{\circ} \mathrm{C}$. After this period, the nonsolubilized samples were separated and dried in oven at $105^{\circ} \mathrm{C}$ for $24 \mathrm{~h}$ to determine the final dry matter. Water solubility of the films was calculated as percentage weight that remained after water immersion, using Equation (1).

$$
\text { Solubility in water }(\%)=\frac{\operatorname{idf}(g)-\mathrm{fdf}(\mathrm{g})}{\operatorname{idf}(\mathrm{g})} \times 100
$$

in which 'idf' is the initial dry mass of films $(\mathrm{g})$ and ' $\mathrm{fdf}^{\prime}$ ' is the final dry mass of nonsolubilized films $(\mathrm{g})$.

\subsubsection{Water Vapor Permeability}

Water vapor permeability rate of films was gravimetrically determined based on the ASTM E96-80 method [35]. Film samples of each formulation were fixed individually in the central opening (diameter $4.3 \mathrm{~cm}$ ) of acrylic cells, filled at the bottom with dry calcium chloride $\left(0 \%\right.$ relative humidity at $\left.25^{\circ} \mathrm{C}\right)$. Cells were allocated in a desiccator containing saturated sodium chloride $\left(75 \pm 3 \%\right.$ relative humidity at $\left.25^{\circ} \mathrm{C}\right)$. Water vapor transferred through films was measured by calcium chloride mass gain. The cells were weighed every $24 \mathrm{~h}$ for 7 days. Water vapor permeation rate (WVP) was determined using Equation (2).

$$
\mathrm{WVP}=\frac{\mathrm{T}}{\mathrm{A} \times \Delta \mathrm{P}} \times \mathrm{M}
$$

in which 'WVP' is permeability to water vapor $\left(\mathrm{g} \mathrm{mm} / \mathrm{m}^{2}\right.$ day $\left.\mathrm{kPa}\right)$, ' $\mathrm{T}$ ' is mean film thickness $(\mathrm{mm})$ of the 5 random measurements made on different parts of film, ' $\mathrm{A}^{\prime}$ is permeation area $\left(\mathrm{m}^{2}\right),{ }^{\prime} \Delta \mathrm{P}^{\prime}$ is partial vapor pressure difference between two sides of films $\left(\mathrm{kPa}\right.$, at $\left.25^{\circ} \mathrm{C}\right)$, and ' $\mathrm{M}$ ' is absorbed moisture rate calculated by linear regression of weight gain and time, in steady state (g/day). 


\subsection{Statistical Analyses}

The SAS program was used for calculating analysis of variance (ANOVA) and the Tukey test to evaluate differences between means with $95 \%$ of confidence.

\section{Results and Discussion}

\subsection{Characterization of the Grape Pomace Extract (GPE)}

The grape pomace extract showed a color between purple and dark blue, and the results of its physical-chemical characterization are shown in Table 1. The water content of the extract was about 91\% (Table 1). Fresh Cabernet Sauvignon grapes had a moisture content of $82 \% \pm 0.9$ and their skin and seed by-products produced during winemaking presented $66 \% \pm 1.0$ and $37 \% \pm 3.4$, respectively [36]. In the present work, the high moisture content is justifiable, since water was used as a solvent for the preparation of the GPE. Water was used to facilitate the process of crushing the grape skins and pomace, and to enable greater disruption of the vegetal cell wall and consequent extraction of soluble compounds such as anthocyanins. The grape pomace extract showed high content of anthocyanins (159.27 $\pm 2.73 \mathrm{mg} / 100 \mathrm{~g}$ of GPE solids), higher than that observed for whole grapes $(96.11 \pm 4.00 \mathrm{mg} / 100 \mathrm{~g}$ of solids) and the must $(74.541 \pm 0.81 \mathrm{mg} / 100 \mathrm{~g}$ of solids). Those results demonstrate that the method used for preparing the extract was efficient for extracting anthocyanins from grape skins. Valduga et al. [37] extracted anthocyanins from grape pomace of cultivar Isabel (Vitis labrusca) and obtained total anthocyanin content of $300 \mathrm{mg} / 100 \mathrm{~g}^{-1}$. Most of the anthocyanins present in grapes are concentrated in their skins [15]. Peonidin-3-O-glucoside was the dominant anthocyanin pigment in Kotsifali grape skin extracts, [38]. Studies have shown that the composition and amount of anthocyanins present in grapes, skins/pomace, and seeds vary according to the variety, cultivar [38], maturity [39], location of vineyards, climatic conditions [40], and geographic origin [41].

Table 1. Characterization of grape pomace extract (GPE).

\begin{tabular}{cc}
\hline Analysis & Grape Pomace Extract (GPE) ${ }^{\mathbf{1}}$ \\
\hline Moisture content $(\%-$ w.b.) & $91.29 \pm 0.14$ \\
Total soluble solids ( ${ }^{\circ}$ Brix) & $12.05 \pm 0.11$ \\
pH (decimal) & $3.70 \pm 0.01$ \\
Total titratable acidity (g of tartaric acid/100 g of GPE) & $5.60 \pm 0.04$ \\
Total anthocyanins (mg/100 g of GPE solids) & $159.27 \pm 2.73$ \\
\hline
\end{tabular}

${ }^{1}$ Results are means of three determinations \pm standard deviation.

Regarding the total soluble solids, the grape pomace extract had an average value of $12.05 \pm 0.11^{\circ}$ Brix, similar to that reported for the skin $\left(12.2^{\circ}\right.$ Brix $)$ of grape of the variety Tempranillo [36]. Among the soluble solids dissolved in fruit pulp, organic acids and sugars are important compounds responsible for flavor and its resulting acceptability by consumers [42]. The concentration of soluble sugars tends to increase during fruit ripening, while organic acids tend to decrease, allowing for an organoleptic balance between sweet and sour. Thus, its incorporation into the arrowroot starch matrix will provide innovative flavors to the resulting film. When arrowroot starch films with and without cranberry powder were tasted by 56 tasters during sensory analysis, only $36 \%$ of them rated the flavor of the film without cranberry from "like slightly" to "like extremely", while more than $80 \%$ of the tasters rated these grades for films with $55 \%$ cranberry incorporated [43].

The grape pomace extract showed an acidic $\mathrm{pH}$ due to high acidity (Table 1), staying within the $\mathrm{pH}$ reported by Camargo et al. [4] for grapes of cultivar BRS Violeta ( $\mathrm{pH}$ between 3.70 and 3.80). The husks of Italia, Brasil, Rubi, Thompson, and Niagara varieties presented $\mathrm{pH}$ values of $4.53,4.13,4.66,4.09$, and 4.03 , respectively [44]. The total titratable acidity of grape pomace extract was $5.60 \pm 0.04 \mathrm{~g}$ of tartaric acid/100 $\mathrm{g}$ of GPE. This value is lower than the $16.19 \pm 3.12 \%$ obtained by Andrade et al. [45] for grape skin of the Aragonez variety. Ribeiro et al. [36] performed chemical determination of winemaking by-products 
from grape varieties grown in São Francisco Valley, Brazil. The authors reported values ranging from 1.22 to $4.61 \mathrm{~g}$ of tartaric acid $/ 100 \mathrm{~mL}^{-1}$ for the skin of grape varieties Alicante Bouschet, Cabernet Sauvignon, Syrah, and Tempranillo used in red wines processing. In this type of processing, high acidity is common, as soon after the grapes' maceration, alcoholic fermentation begins with production of succinic, lactic, and acetic acids, in addition to the predominant acids (such as malic, citric, and tartaric acids) in the grapes ripening [36].

\subsection{Characterization of Edible Films}

\subsubsection{Visual Aspect}

Regarding the handling characteristics, after drying, all films were removed from the support plates without tearing, except for the control film, which was brittle. Upon manual contact, it was observed that the control film produced only with arrowroot starch and glycerol was drier and less flexible compared to the films incorporated in grape pomace extract, which were more flexible to handle. The more extract incorporated, the more malleable the films were. All prepared films had a smooth, bubble-free surface and had a matte and a glossy side.

As expected, the film sample with grape pomace extract showed a reddish hue due to anthocyanin-derived pigments present in the grape, which also caused a visible reduction in transparency of the arrowroot starch film to the naked eye. The grape pomace extract had an intense dark purple color starting to have an outstanding visual effect on the color of the films in which it was incorporated. Furthermore, the increasing concentration of grape pomace extract $(20,30$, and $40 \%$ GPE) led to a visibly clear increase in the reddish color of the films, different from films without extract ( $0 \%$ GPE) which were colorless, as shown in the images of Figure 1. Films produced with tara gum and cellulose nanocrystal had their color changed from pale yellow to brown when extracts from grape skins were added [21]. Films of corn starch and glycerol incorporated with blueberry powder (co-product from juice processing) had visually darker colors when the fruits were pre-bleached, while the unbleached samples had a lighter color and greater brightness [46].

\begin{tabular}{lllll}
\hline \multicolumn{5}{c}{ Edible Films } \\
\hline & $0 \%$ GPE & $20 \%$ GPE & $30 \%$ GPE & $40 \%$ GPE \\
\hline $\begin{array}{l}\text { Film side } 1 \\
\text { (glossy side) }\end{array}$ & & & & \\
\hline
\end{tabular}

Figure 1. Digital photographs of the edible films of arrowroot (Maranta arundinacea Linn.) starch with $0,20,30$, and $40 \%$ of grape pomace extract (GPE).

Generally, films should be as colorless as possible to approximate the appearance of plastic packaging when used as replacement [21,47]. However, for edible films, color is an important characteristic as it generates sensory attractiveness. The panelists in the sensory analysis approved arrowroot starch films incorporated with powdered cranberry. More than $77 \%$ of testers gave scores between "like it slightly" and "like it a lot" to the 
appearance and color attributes of cranberry films, which had a slightly pinkish tinge [43]. With that in mind, for edible films that can be consumed along with packaged food or fruit strips, the color can be an attractive factor for consumer acceptance. This is because, when the grape pomace extract is incorporated in the films, the development of colors close to the hue of grape is expected due to the presence of anthocyanins pigment in its composition, in addition to the development of characteristic flavors of the fruit. Otherwise, the polymeric chain of the film can also be used as a strategy to alleviate undesirable flavors and odors of fruits, extracts, or isolated bioactive compounds, acting as an encapsulant [48]. Moreover, the incorporation of grape pomace extract in polymeric film matrices can be used as a strategy to protect nutritional and bioactive compounds against $\mathrm{pH}$, light, oxygen, among other factors that can lead to its oxidation, allowing its stabilization [43]. Flexible polymeric film containing one or more active ingredients dispersed and/or dissolved can be used as an important transport vehicle for oral delivery of active compounds, whose disintegration can occur in saliva without chewing or with water ingestion [48-50]. Tedesco et al. [20] elaborated films for oral disintegration from carboxymethylcellulose, hydroxypropylmethylcellulose, and pregelatinized starch incorporated with ethanol extract of dehydrated acerola waste as source of phenolic compounds.

\subsubsection{Water Activity and Water Content of Edible Films}

The relative humidity of the environment directly influences the water content and water activity of foods, with water activity being the environmental factor that most affects lipid oxidation reactions, enzymatic and non-enzymatic reactions, and microbiological growth, processes that are normally involved with deterioration in food products [51]. The water activity and water content results for the edible films evaluated after their storage in controlled environment (temperature of $25^{\circ} \mathrm{C}$ and $55 \pm 3 \%$ of relative humidity) for $48 \mathrm{~h}$ are presented in Table 2.

Table 2. Water activity and water content of edible films of arrowroot (Maranta arundinacea Linn.) starch with $0,20,30$, and $40 \%$ of grape pomace extract (GPE).

\begin{tabular}{|c|c|c|c|c|}
\hline \multirow{2}{*}{ Analysis } & \multicolumn{4}{|c|}{ Edible Film $^{1}$} \\
\hline & $0 \%$ GPE & $20 \%$ GPE & $30 \%$ GPE & $40 \%$ GPE \\
\hline $\begin{array}{l}\text { Water activity } \\
\text { (decimal) }\end{array}$ & $0.47 \pm 0.02 \mathrm{a}$ & $0.50 \pm 0.01 \mathrm{a}$ & $0.50 \pm 0.01 \mathrm{a}$ & $0.49 \pm 0.03 a$ \\
\hline $\begin{array}{l}\text { Moisture content } \\
\quad(\%-\text { w.b. })\end{array}$ & $8.17 \pm 0.21 c$ & $10.68 \pm 0.45 b$ & $11.75 \pm 0.40 \mathrm{ba}$ & $12.48 \pm 0.38 \mathrm{a}$ \\
\hline
\end{tabular}

${ }^{1}$ Results are the means of three determinations \pm standard deviation. Values with the same letter in the same row do not statistically differ by Tukey's test $(p<0.05)$.

Food water activity is an important indicator for predicting and controlling food stability in relation to sensory, physical, chemical properties, harmful reaction rates, and microbial growth [52]. For edible films, it is desirable that its water activity is below 0.60 in order to prevent the proliferation of microorganisms and to reduce hydrolytic and enzymatic reactions, allowing the guarantee of food safety for consumption [53]. The water activity of the films was not significantly influenced by concentration of incorporated grape pomace extract. Arrowroot starch films with and without grape pomace extract showed mean values of water activity equal to or less than 0.50 , demonstrating stability against microbial proliferation. Cassava starch films had water activity values ranging between 0.66 and 0.70 [54]. Controlling water activity is one of the main factors for maintaining intermediate moisture and consequently preserving dry foods.

Water content of the films increased significantly $(p<0.05)$ from $10.68 \pm 0.45 \%$ to $12.48 \pm 0.38 \%$ with the increase from $20 \%$ to $40 \%$ GPE incorporated in arrowroot starch films, which presented $8.17 \pm 0.21 \%$ (w.b.) of moisture content. Similar performance was observed by Bodini et al. [19] for starch and hydroxypropylmethylcellulose films with different concentrations of Cordia verbenacea (whaling grass) extract. The moisture content 
of the films is directly related to hydrophilic characteristic of the extract incorporated in polymeric matrix of the film [49]. Furthermore, it is important to emphasize that the moisture content of the films can also affect the microstructure of starch network, since water molecules can be trapped in micropores present in the network [49,55].

The moisture content of the films with and without grape pomace extract was still lower than those reported for carboxymethylcellulose films incorporated with blueberry pomace extract and red grape skin pomace extract which ranged from $13.36 \pm 0.61 \%$ to $16.82 \pm 0.79 \%$ [15]. Films made of chitosan and red apple pomace extract presented $26.28 \pm 0.81 \%$ of moisture content [17].

\subsubsection{Thickness of Edible Films}

Figure 2 shows the thickness of edible films. It was found that increasing the concentration from $20 \%, 30 \%$, to $40 \%$ of the grape pomace extract in the arrowroot starch film-forming solution promoted a significant $(p<0.05)$ effect on thickness of the film $(0 \%$ GPE). The more extract incorporated, the thicker the resulting film, compared to the control film ( $0 \%$ GPE). This addition in film thickness can be attributed to the increase for solids (coming from the grape pomace extract) in the polymer matrix.

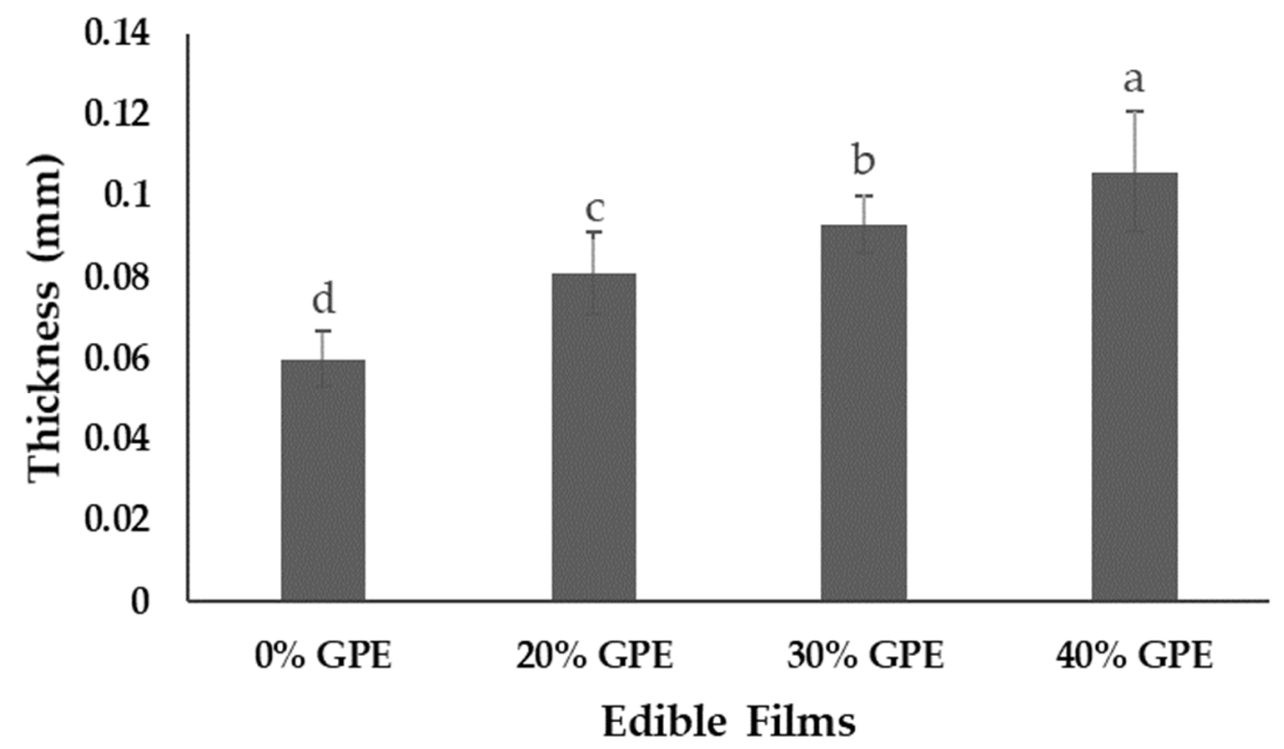

Figure 2. Thickness (mm) of edible films of arrowroot (Maranta arundinacea Linn.) starch with 0 , 20,30 , and $40 \%$ of grape pomace extract (GPE). Values with the same letter in the columns do not statistically differ by Tukey's test $(p<0.05)$.

Arrowroot starch film thickness increased significantly $(p<0.05)$ from $0.060 \pm 0.007$ to $0.106 \pm 0.015 \mathrm{~mm}$ after addition of grape pomace extract. Similar results were observed by Lan et al. [17] for chitosan-based films with nanosized $\mathrm{TiO}_{2}$ and red apple pomace extract. Staroszczyk et al. [56] produced fish gelatin films added with aqueous extracts from rowanberry, blue-berried honeysuckle, and chokeberry pomace with an average thickness of $0.0603 \pm 0.0009 \mathrm{~mm}$. Increasing the concentration of raspberry pomace extracts $(0.5 \mathrm{~g} / \mathrm{L}$, $1.5 \mathrm{~g} / \mathrm{L}$, and $3 \mathrm{~g} / \mathrm{L}$ ) added to a compound film of pectin/sodium alginate/xanthan gum led to a significant decrease in thickness of the films from $0.56 \mathrm{~mm}$ to $0.41 \mathrm{~mm}$. According to the authors, Fourier transform infrared and scanning electron microscopy analysis showed raspberry pomace extract had good compatibility with film matrix. Therefore, it is possible that intermolecular bonds between the raspberry pomace extract and the film matrix led to the formation of a more rigid and compact polymer chain [18]. 


\subsubsection{Solubility in Water of Edible Films}

Water solubility of biopolymeric films is a very important property as it is indicative of their affinity with water [15]. Low water solubility is desired to maintain the integrity of films when it is used for packaging foods with a high moisture content [6,15]. However, a high solubility in water is required when the films are used as encapsulant, ingested with the packaged product, or even consumed alone as fruit strips [57]. In these specific cases, the films must be able to disintegrate after consumption (in the oral cavity) [50] or during their passage to the gastrointestinal tract [58].

The effect of addition of GPE on water solubility of the films can be viewed in Figure 3. The increase of GPE concentration from $20 \%$ to $30 \%$ or $40 \%$ in the film ( $0 \%$ GPE) promoted a significant increase $(p<0.05)$ in water solubility from $13.33 \pm 0.32 \%$ to $33.32 \pm 1.89 \%$, an increase of 2.50 orders of magnitude. Similarly, Prietto et al. [22] found that the addition of anthocyanins extracted from black bean seed coat and red cabbage provided increase in water solubility of corn starch films. The incorporation of aqueous extracts from rowanberry, blue-berried honeysuckle, and chokeberry pomace did not significantly alter the water solubility of fish gelatin films, staying between $81.5 \pm 6.52 \%$ and $89.3 \pm 1.79 \%$ [56]. Films of pectin/sodium alginate/xanthan gum reduced solubility in water after incorporation of raspberry from $59.58 \pm 0.56 \%$ to $48.57 \%$ [18]. Carboxymethylcellulose films with or without blueberry pomace extract and red grape skin pomace extract were $100 \%$ water soluble [15].



\section{Edible Films}

Figure 3. Water solubility of edible films of arrowroot (Maranta arundinacea Linn.) starch with 0 , 20,30 , and $40 \%$ of grape pomace extract (GPE). Values with the same letter in the columns do not statistically differ by Tukey's test $(p<0.05)$.

In the present study, the increase in water solubility of arrowroot starch films can be attributed to the increase of hydrophilicity of polymer matrix after the incorporation of aqueous extract of grape pomace [15]. This increase in hydrophilic portion provides the film with a greater predisposition to interact with water, facilitating its solubilization. These results also point out that the extract may have behaved as plasticizer in the films, leading to a reduction in matrix cohesiveness, and a consequent increase in polymer chain mobility, which contributed to the transfer of water into its structure and solubilization [19]. This behavior could be associated with the plasticizing effect of water and sugars present in the extract (Table 1) when added to the polymer matrix $[43,59,60]$ or other compounds such as soluble dietary fiber [1]. 


\subsubsection{Water Vapor Permeability of Edible Films}

The results of water vapor barrier property for produced films are represented in Figure 4 . The increase in extract concentration caused an increase in water vapor permeability of the films, following the same trend observed for the water solubility of films (Figure 3). It was not possible to analyze water vapor permeability of the control film, as all samples burst during the analysis, probably because they could not withstand the pressure exerted by water vapor when transferred through the film due to the high rigidity of the polymer chain. This fact demonstrates that water vapor permeability of the films was strongly influenced by concentration of added grape pomace extract. Probably different intermolecular interactions in polymer matrix were formed after addition of the extract, such as starch-GPE, starch-water, sugars-starch, and soluble fiber-starch interactions.

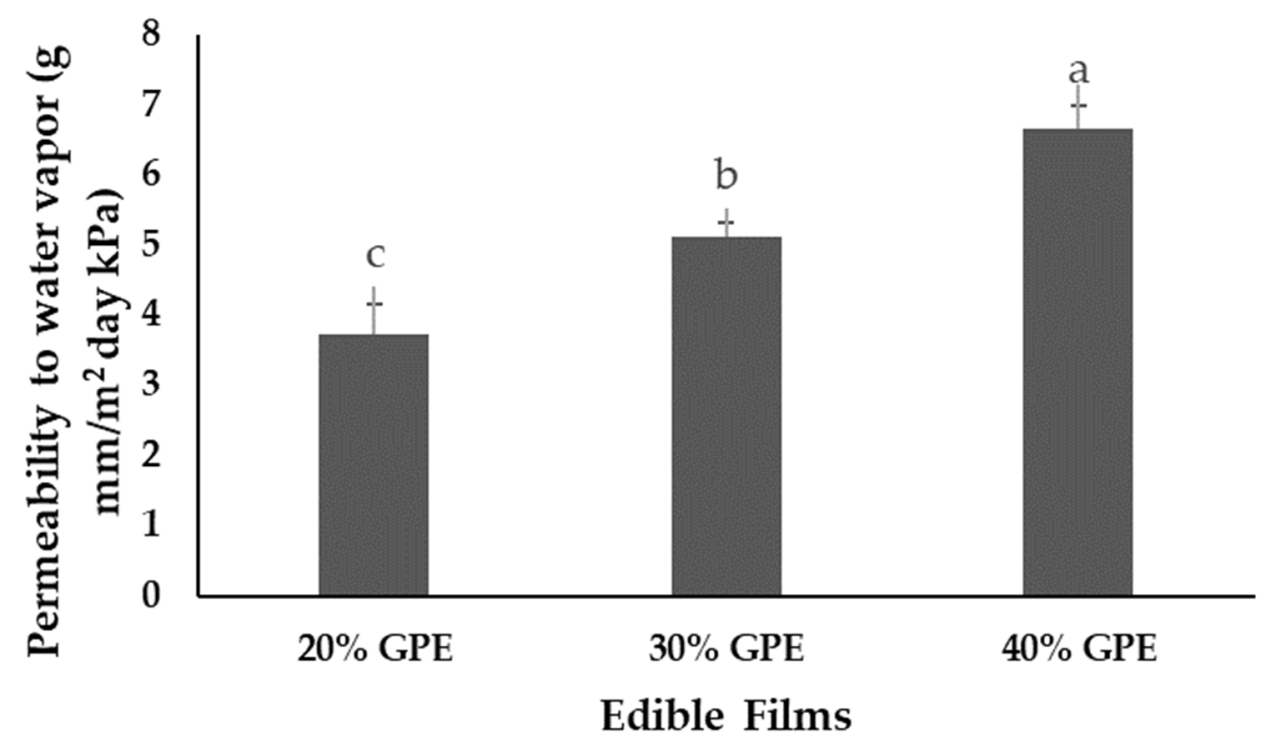

Figure 4. Water vapor permeability of edible films of arrowroot (Maranta arundinacea Linn.) starch with $0,20,30$, and $40 \%$ of grape pomace extract (GPE). Values with the same letter in the columns do not statistically differ by Tukey's test $(p<0.05)$.

The hypothesis is that sugars and soluble dietary fiber present in grape pomace extract reduced intermolecular forces of attraction of starch chain, thus increasing the free volume of the system and the mobility of the chain, which facilitated permeation of water vapor through the film structure [43]. Although the content of soluble dietary fiber in extract has not been quantified, it is known that grape pomace is a rich source of soluble hemicellulose, pectins, gums, and mucilages present in the cell wall [1]. It is supposed that during the obtaining of grape pomace extract, these compounds were carried and incorporated into the films. In future works, the amount of soluble dietary fiber present in the GPE should be performed to confirm this hypothesis.

Transfer of water vapor usually occurs through the hydrophilic portion of the film. Therefore, it is believed that the addition of aqueous extract of grape pomace contributed to a higher concentration of polar groups $(-\mathrm{OH})$ available for interactions with water molecules [15]. Increasing the concentration from 20 to $40 \%$ of grape pomace extract in arrowroot starch film produced about $79 \%$ increase in its water vapor permeability value, similar to results obtained by Kurek [15]. Chitosan films with higher concentration of red grape skin pomace extract $(4 \%)$ exhibited greater permeability to water vapor parallel to lower concentrations (1 and 2\%) [15]. In contrast, water vapor permeability of chitosan films and composite films decreased with the incorporation of red apple pomace extract and raspberry pomace extracts, respectively $[17,18]$. The authors attributed this behavior to a decrease in affinity of the film with water vapor due to the incorporation of bulky aromatic rings of phenolic skeleton in the extract $[17,18]$. These results indicate that the barrier 
properties of the film are directly influenced by type of polymers used in the production of films, the composition of incorporated extract, and conditions used in preparation of this extract [56].

\section{Conclusions}

In this research, arrowroot starch films with grape pomace extract were developed. The addition of the extract significantly changed the color, thickness, moisture content, water solubility, and water vapor permeability of arrowroot starch films. The extract-added films were visually reddish, differing from the control film which was colorless and more transparent. The grape pomace extract had high acidity, high moisture content, and more soluble solids, in addition to showing itself as a good source of anthocyanins, the pigments responsible for its dark purplish color. Films with grape pomace extract were more flexible to handle than films without extract. The higher concentration of grape pomace extract incorporated in the film, the thicker, more water-soluble, and more permeable they were compared to the control film, indicating different intermolecular interactions in polymer chain, such as starch-GPE, starch-water, sugars-starch, and soluble fiber-starch interactions. Although it is alleged that the addition of grape pomace extract leads to an increase in the hydrolytic portion of the film and, consequently, to an addition in its interaction with water, more advanced analyses need to be carried out for this confirmation, such as Fouriertransform infrared spectroscopy (FTIR) analysis. Furthermore, the extract may have acted as a plasticizer, leading to the formation of a less cohesive polymer chain with greater mobility, which facilitated the permeation of water through the film. However, structural changes in the film chain should be confirmed in future morphological analyses. For edible films, it is desirable that they are soluble and permeable to water. Based on the results, it can be predicted that the arrowroot starch films with grape pomace extract have great potential to be consumed with packaged food or as fruits strips. Future studies can explore the formation of edible films for the elaboration of nutraceutical products with functional appeal by using agro-industrial by-products such as natural extract of grape pomace.

Author Contributions: G.F.N.: conceptualization, data collection, analysis, interpretation, writingoriginal draft preparation, writing — review and editing, visualization, and supervision. I.H.B.T.S.: methodology, formal analysis, investigation, and writing-original draft preparation. C.T.S.: methodology, software, validation, formal analysis, investigation, and writing-original draft preparation. F.M.F.: methodology, writing-review and editing, and supervision. R.A.d.O.: conceptualization, resources, writing - review and editing, visualization, supervision, project administration, and funding acquisition. All authors have read and agreed to the published version of the manuscript.

Funding: This research was funded by Serviço de Apoio ao Estudante-SAE and by Pró-Reitoria de Pesquisa-PRP/UNICAMP.

Institutional Review Board Statement: Not applicable.

Informed Consent Statement: Not applicable.

Data Availability Statement: Data sharing not applicable.

Acknowledgments: The authors are grateful to the to the Research Office of University of Campinas and to the School of Agricultural Engineering-University of Campinas for their administrative, technical support, or donations in kind (e.g., materials used for experiments). The author Farayde Matta Fakhouri is a Serra Hunter Fellow.

Conflicts of Interest: The authors declare no conflict of interest. The funders had no role in the design of the study; in the collection, analyses, or interpretation of data; in the writing of the manuscript; or in the decision to publish the results. 


\section{References}

1. Colodel, C.; Vriesmann, L.C.; Teófilo, R.F.; de Oliveira Petkowicz, C.L. Optimization of Acid-Extraction of Pectic Fraction from Grape (Vitis Vinifera Cv. Chardonnay) Pomace, a Winery Waste. Int. J. Biol. Macromol. 2020, 161, 204-213. [CrossRef] [PubMed]

2. Gomes, R. Produção Nacional de Vinhos Deve Fechar em Alta com Boas Perspectivas para 2022. Available online: https:/ / www.bemminas.com.br/noticias/artigos/producao-nacional-de-vinhos-deve-fechar-em-alta-com-boas-perspectivaspara-2022/11641 (accessed on 2 February 2022).

3. De Mello, L.M.R.; Machado, C.A.E. Vitivinicultura Brasileira: Panorama 2019; Brazilian Agricultural Research Corporation: Brasília, Brazil, 2020.

4. Camargo, U.A.; Maia, J.D.G.; Nachtigal, J.C. Comunicado Técnico 63: BRS Violeta: Nova Cultivar de Uva para Suco e Vinho de Mesa; Brazilian Agricultural Research Corporation: Bento Gonçalves, RS, Brazil; Embrapa Grape \& Wine: Bento Gonçalves, RS, Brazil, 2005.

5. $\quad$ Beres, C.; Costa, G.N.S.; Cabezudo, I.; da Silva-James, N.K.; Teles, A.S.C.; Cruz, A.P.G.; Mellinger-Silva, C.; Tonon, R.V.; Cabral, L.M.C.; Freitas, S.P. Towards Integral Utilization of Grape Pomace from Winemaking Process: A Review. Waste Manag. 2017, 68, 581-594. [CrossRef] [PubMed]

6. Ferreira, A.S.; Nunes, C.; Castro, A.; Ferreira, P.; Coimbra, M.A. Influence of Grape Pomace Extract Incorporation on Chitosan Films Properties. Carbohydr. Polym. 2014, 113, 490-499. [CrossRef] [PubMed]

7. Moro, K.I.B.; Bender, A.B.B.; de Freitas Ferreira, D.; Speroni, C.S.; Barin, J.S.; da Silva, L.P.; Penna, N.G. Recovery of Phenolic Compounds from Grape Pomace (Vitis vinifera L.) by Microwave Hydrodiffusion and Gravity. LWT 2021, 150, 112066. [CrossRef]

8. Milinčić, D.D.; Stanisavljević, N.S.; Kostić, A.Ž.; Soković Bajić, S.; Kojić, M.O.; Gašić, U.M.; Barać, M.B.; Stanojević, S.P.; Lj Tešić, Ž.; Pešić, M.B. Phenolic Compounds and Biopotential of Grape Pomace Extracts from Prokupac Red Grape Variety. LWT 2021, 138, 110739. [CrossRef]

9. Bruno Romanini, E.; Misturini Rodrigues, L.; Finger, A.; Perez Cantuaria Chierrito, T.; Regina da Silva Scapim, M.; Scaramal Madrona, G. Ultrasound Assisted Extraction of Bioactive Compounds from BRS Violet Grape Pomace Followed by Alginate-Ca ${ }^{2+}$ Encapsulation. Food Chem. 2021, 338, 128101. [CrossRef]

10. Dong, X.; Zhu, C.-P.; Huang, G.-Q.; Xiao, J.-X. Fractionation and Structural Characterization of Polysaccharides Derived from Red Grape Pomace. Process Biochem. 2021, 109, 37-45. [CrossRef]

11. Ilyas, T.; Chowdhary, P.; Chaurasia, D.; Gnansounou, E.; Pandey, A.; Chaturvedi, P. Sustainable Green Processing of Grape Pomace for the Production of Value-Added Products: An Overview. Environ. Technol. Innov. 2021, 23, 101592. [CrossRef]

12. Balli, D.; Cecchi, L.; Innocenti, M.; Bellumori, M.; Mulinacci, N. Food By-Products Valorisation: Grape Pomace and Olive Pomace (Pâté) as Sources of Phenolic Compounds and Fiber for Enrichment of Tagliatelle Pasta. Food Chem. 2021, 355, 129642. [CrossRef]

13. Nakov, G.; Brandolini, A.; Hidalgo, A.; Ivanova, N.; Stamatovska, V.; Dimov, I. Effect of Grape Pomace Powder Addition on Chemical, Nutritional and Technological Properties of Cakes. LWT 2020, 134, 109950. [CrossRef]

14. Costa, J.R.; Monteiro, M.J.; Tonon, R.V.; Cabral, L.M.C.; Pastrana, L.; Pintado, M.E. Fortification of Coconut Water with Microencapsulated Grape Pomace Extract towards a Novel Electrolyte Beverage: Biological, Sensorial and Quality Aspects. Future Foods 2021, 4, 100079. [CrossRef]

15. Kurek, M.; Hlupić, L.; Elez Garofulić, I.; Descours, E.; Ščetar, M.; Galić, K. Comparison of Protective Supports and Antioxidative Capacity of Two Bio-Based Films with Revalorised Fruit Pomaces Extracted from Blueberry and Red Grape Skin. Food Packag. Shelf Life 2019, 20, 100315. [CrossRef]

16. Gutiérrez, T.J.; Herniou-Julien, C.; Álvarez, K.; Alvarez, V.A. Structural Properties and in Vitro Digestibility of Edible and PH-Sensitive Films Made from Guinea Arrowroot Starch and Wastes from Wine Manufacture. Carbohydr. Polym. 2018, 184, 135-143. [CrossRef] [PubMed]

17. Lan, W.; Wang, S.; Zhang, Z.; Liang, X.; Liu, X.; Zhang, J. Development of Red Apple Pomace Extract/Chitosan-Based Films Reinforced by TiO2 Nanoparticles as a Multifunctional Packaging Material. Int. J. Biol. Macromol. 2021, 168, 105-115. [CrossRef]

18. Yang, J.; Fan, Y.; Cui, J.; Yang, L.; Su, H.; Yang, P.; Pan, J. Colorimetric Films Based on Pectin/Sodium Alginate/Xanthan Gum Incorporated with Raspberry Pomace Extract for Monitoring Protein-Rich Food Freshness. Int. J. Biol. Macromol. 2021, 185, 959-965. [CrossRef]

19. Bodini, R.B.; Pugine, S.M.P.; de Melo, M.P.; de Carvalho, R.A. Antioxidant and Anti-Inflammatory Properties of Orally Disintegrating Films Based on Starch and Hydroxypropyl Methylcellulose Incorporated with Cordia Verbenacea (Erva Baleeira) Extract. Int. J. Biol. Macromol. 2020, 159, 714-724. [CrossRef]

20. Tedesco, M.P.; dos Santos Garcia, V.A.; Borges, J.G.; Osiro, D.; Vanin, F.M.; Pedroso Yoshida, C.M.; de Carvalho, R.A. Production of Oral Films Based on Pre-Gelatinized Starch, CMC and HPMC for Delivery of Bioactive Compounds Extract from Acerola Industrial Waste. Ind. Crop. Prod. 2021, 170, 113684. [CrossRef]

21. Ma, Q.; Wang, L. Preparation of a Visual PH-Sensing Film Based on Tara Gum Incorporating Cellulose and Extracts from Grape Skins. Sens. Actuators B Chem. 2016, 235, 401-407. [CrossRef]

22. Prietto, L.; Mirapalhete, T.C.; Pinto, V.Z.; Hoffmann, J.F.; Vanier, N.L.; Lim, L.-T.; Guerra Dias, A.R.; da Rosa Zavareze, E. PH-Sensitive Films Containing Anthocyanins Extracted from Black Bean Seed Coat and Red Cabbage. LWT 2017, 80, 492-500. [CrossRef]

23. Nogueira, G.F.; de Oliveira, R.A.; Velasco, J.I.; Fakhouri, F.M. Methods of Incorporating Plant-Derived Bioactive Compounds into Films Made with Agro-Based Polymers for Application as Food Packaging: A Brief Review. Polymers 2020, 12, 2518. [CrossRef] 
24. Nogueira, G.F.; Fakhouri, F.M.; de Oliveira, R.A. Extraction and Characterization of Arrowroot (Maranta Arundinaceae L.) Starch and Its Application in Edible Films. Carbohydr. Polym. 2018, 186, 64-72. [CrossRef] [PubMed]

25. Villas-Boas, F.; Franco, C.M.L. Effect of Bacterial $\beta$-Amylase and Fungal $\alpha$-Amylase on the Digestibility and Structural Characteristics of Potato and Arrowroot Starches. Food Hydrocoll. 2016, 52, 795-803. [CrossRef]

26. De Souza, D.C.; de Silva, R.J.; Guerra, T.S.; de Silva, L.F.L.; Resende, L.V.; Pereira, J. Characterization of Arrowroot Starch in Different Agronomic Managements. Rev. Ceres 2019, 66, 323-332. [CrossRef]

27. Chan, S.Y.; Goh, C.F.; Lau, J.Y.; Tiew, Y.C.; Balakrishnan, T. Rice Starch Thin Films as a Potential Buccal Delivery System: Effect of Plasticiser and Drug Loading on Drug Release Profile. Int. J. Pharm. 2019, 562, 203-211. [CrossRef]

28. Horwitz, W.; Latimer, G.W.; Association of Official Analytical Chemists International. Official Methods of Analysis of AOAC International; AOAC International: Gaithersburg, MD, USA, 2006; ISBN 0-935584-77-3.

29. Martínez, C.; Centro Internacional de Agricultura Tropical. Evaluación de La Calidad Culinaria y Molinera Del Arroz; CIAT Serie 04SR-07.01; Centro Internacional de Agricultura Tropical (CIAT): Cali, Colombia, 1989.

30. Cunniff, P.; Association of Official Analytical Chemists. Official Methods of Analysis of AOAC International; Association of Official Analytical Chemists: Washington, DC, USA, 1995; ISBN 978-0-935584-54-7.

31. Sims, D.A.; Gamon, J.A. Relationships between Leaf Pigment Content and Spectral Reflectance across a Wide Range of Species, Leaf Structures and Developmental Stages. Remote Sens. Environ. 2002, 81, 337-354. [CrossRef]

32. Nogueira, G.F.; Soares, C.T.; Cavasini, R.; Fakhouri, F.M.; de Oliveira, R.A. Bioactive Films of Arrowroot Starch and Blackberry Pulp: Physical, Mechanical and Barrier Properties and Stability to PH and Sterilization. Food Chem. 2019, 275, 417-425. [CrossRef]

33. Nogueira, G.F.; Fakhouri, F.M.; Velasco, J.I.; de Oliveira, R.A. Active Edible Films Based on Arrowroot Starch with Microparticles of Blackberry Pulp Obtained by Freeze-Drying for Food Packaging. Polymers 2019, 11, 1382. [CrossRef]

34. Gontard, N.; Guilbert, S.; Cuq, J.-L. Edible Wheat Gluten Films: Influence of the Main Process Variables on Film Properties Using Response Surface Methodology. J. Food Sci. 1992, 57, 190-195. [CrossRef]

35. ASTM Standard Test Methods for Water Vapor Transmission of Materials. Method E96e80. In Annual Book of American Standard Testing Methods; ASTM International: West Conshohocken, PA, USA, 1989.

36. Ribeiro, T.P.; de Lima, M.A.C.; Alves, R.E.; de Gonçalves, A.L.; Souza, A.P.C. Chemical Characterization of Winemaking Byproducts from Grape Varieties Cultivated in Vale Do São Francisco, Brazil. Food Sci. Technol. 2018, 38, 577-583. [CrossRef]

37. Valduga, E.; Lima, L.; do Prado, R.; Padilha, F.F.; Treichel, H. Extração, Secagem Por Atomização e Microencapsulamento de Antocianinas Do Bagaço Da Uva "Isabel" (Vitis Labrusca). Ciênc. Agrotecnol. 2008, 32, 1568-1574. [CrossRef]

38. Kyraleou, M.; Kallithraka, S.; Gkanidi, E.; Koundouras, S.; Mannion, D.T.; Kilcawley, K.N. Discrimination of Five Greek Red Grape Varieties According to the Anthocyanin and Proanthocyanidin Profiles of Their Skins and Seeds. J. Food Compos. Anal. 2020, 92, 103547. [CrossRef]

39. Xie, S.; Liu, Y.; Chen, H.; Zhang, Z.; Ge, M. Anthocyanin Degradation and the Underlying Molecular Mechanism in a Red-Fleshed Grape Variety. LWT 2021, 151, 112198. [CrossRef]

40. Kharadze, M.; Japaridze, I.; Kalandia, A.; Vanidze, M. Anthocyanins and Antioxidant Activity of Red Wines Made from Endemic Grape Varieties. Ann. Agrar. Sci. 2018, 16, 181-184. [CrossRef]

41. Sikuten, I.; Stambuk, P.; Tomaz, I.; Marchal, C.; Kontic, J.K.; Lacombe, T.; Maletic, E.; Preiner, D. Discrimination of Genetic and Geographical Groups of Grape Varieties (Vitis vinifera L.) Based on Their Polyphenolic Profiles. J. Food Compos. Anal. 2021, 102, 104062. [CrossRef]

42. Martineli, M.; Mendes, F.T.; dos Santos, J.R.P.; de Maranhão, C.M.; Castricini, A. Avaliação Sensorial e da Qualidade de Uvas-Passas Processadas a Partir de Três Cultivares Produzidas No Semiárido. Braz. J. Food Technol. 2018, 21, e2017131. [CrossRef]

43. Matta Fakhouri, F.; Nogueira, G.F.; de Oliveira, R.A.; Velasco, J.I. Bioactive Edible Films Based on Arrowroot Starch Incorporated with Cranberry Powder: Microstructure, Thermal Properties, Ascorbic Acid Content and Sensory Analysis. Polymers 2019, 11, 1650. [CrossRef]

44. Souza, A.V.D.; Lima, G.P.P.; Vieites, R.L. Avaliação nutricional de diferentes variedades de uva (Vitis sp.). Naturalia 2010, 33, 100-109.

45. De Andrade, R.B.; de Barreto, G.; Guez, M.A.U.; Machado, B.A.S. Quantificação de Compostos Antioxidantes Presentes em Extrato Obtido a Partir de Cascas de Uvas Aragonez. In A Produção do Conhecimento nas Ciências da Saúde 2; Atena Editora: Ponta Grossa, Brazil, 2019; pp. 315-324. ISBN 978-85-7247-299-9.

46. Luchese, C.L.; Sperotto, N.; Spada, J.C.; Tessaro, I.C. Effect of Blueberry Agro-Industrial Waste Addition to Corn Starch-Based Films for the Production of a PH-Indicator Film. Int. J. Biol. Macromol. 2017, 104, 11-18. [CrossRef]

47. Ghanbarzadeh, B.; Almasi, H. Physical Properties of Edible Emulsified Films Based on Carboxymethyl Cellulose and Oleic Acid. Int. J. Biol. Macromol. 2011, 48, 44-49. [CrossRef]

48. Gupta, M.S.; Kumar, T.P.; Gowda, D.V. Orodispersible Thin Film: A New Patient-Centered Innovation. J. Drug Deliv. Sci. Technol. 2020, 59, 101843. [CrossRef]

49. Sha, H.; Yuan, C.; Cui, B.; Zhao, M.; Wang, J. Pre-Gelatinized Cassava Starch Orally Disintegrating Films: Influence of $\beta$ Cyclodextrin. Food Hydrocoll. 2022, 123, 107196. [CrossRef]

50. Maciel, V.B.V.; Remedio, L.N.; Yoshida, C.M.P.; Carvalho, R.A. Carboxymethyl Cellulose-Based Orally Disintegrating Films Enriched with Natural Plant Extract for Oral Iron Delivery. J. Drug Deliv. Sci. Technol. 2021, 66, 102852. [CrossRef]

51. Singh, T.K.; Cadwallader, K.R. The Shelf Life of Foods: An Overview. ACS Symp. Ser. 2002, 836, 2-21. [CrossRef] 
52. Prabhakar, K.; Mallika, E.N. Water Activity. In Encyclopedia of Food Microbiology; Elsevier: Amsterdam, The Netherlands, 2014; pp. 751-754. ISBN 978-0-12-384733-1.

53. McHugh, T.H.; Huxsoll, C.C.; Krochta, J.M. Permeability Properties of Fruit Puree Edible Films. J. Food Sci. $1996,61,88-91$. [CrossRef]

54. Müller, C.M.O.; Yamashita, F.; Laurindo, J.B. Evaluation of the Effects of Glycerol and Sorbitol Concentration and Water Activity on the Water Barrier Properties of Cassava Starch Films through a Solubility Approach. Carbohydr. Polym. 2008, $72,82-87$. [CrossRef]

55. Muscat, D.; Adhikari, B.; Adhikari, R.; Chaudhary, D.S. Comparative Study of Film Forming Behaviour of Low and High Amylose Starches Using Glycerol and Xylitol as Plasticizers. J. Food Eng. 2012, 109, 189-201. [CrossRef]

56. Staroszczyk, H.; Kusznierewicz, B.; Malinowska-Pańczyk, E.; Sinkiewicz, I.; Gottfried, K.; Kołodziejska, I. Fish Gelatin Films Containing Aqueous Extracts from Phenolic-Rich Fruit Pomace. LWT 2020, 117, 108613. [CrossRef]

57. Mukurumbira, A.R.; Mellem, J.J.; Amonsou, E.O. Effects of Amadumbe Starch Nanocrystals on the Physicochemical Properties of Starch Biocomposite Films. Carbohydr. Polym. 2017, 165, 142-148. [CrossRef]

58. Ferreira Nogueira, G.; Matta Fakhouri, F.; de Oliveira, R.A. Incorporation of Spray Dried and Freeze Dried Blackberry Particles in Edible Films: Morphology, Stability to PH, Sterilization and Biodegradation. Food Packag. Shelf Life 2019, 20, 100313. [CrossRef]

59. Otoni, C.G.; de Moura, M.R.; Aouada, F.A.; Camilloto, G.P.; Cruz, R.S.; Lorevice, M.V.; de Soares, F.F.N.; Mattoso, L.H.C. Antimicrobial and Physical-Mechanical Properties of Pectin/Papaya Puree/Cinnamaldehyde Nanoemulsion Edible Composite Films. Food Hydrocoll. 2014, 41, 188-194. [CrossRef]

60. Azeredo, H.M.C.; Morrugares-Carmona, R.; Wellner, N.; Cross, K.; Bajka, B.; Waldron, K.W. Development of Pectin Films with Pomegranate Juice and Citric Acid. Food Chem. 2016, 198, 101-106. [CrossRef] [PubMed] 